\title{
TEKNOLOGI AUGMENTED REALITY DAN KONSEP KONTEKSTUAL PERANCANGAN WISATA PERMAINAN TRADISIONAL DI KOTA TUA
}

\author{
Hugo Herlando ${ }^{1)}$, Petrus Rudi Kasimun ${ }^{2)}$ \\ 1) Program Studi S1 Arsitektur, Fakultas Teknik, Universitas Tarumanagara, herlandohugo@gmail.com \\ 2) Program Studi S1 Arsitektur, Fakultas Teknik, Universitas Tarumanagara, petrusk@ft.untar.ac.id
}

\begin{abstract}
Abstrak
Negara Indonesia memiliki beragam jenis wisata budaya yang menarik dan menghibur, salah satunya yang bersifat kegiatan aktif atau interaktif adalah permainan tradisional. Namun, seiring perkembangan zaman terutama bidang teknologi seperti penggunaan internet, gawai, dan komputer, permainan tradisional yang termasuk budaya itu sudah mulai kehilangan relevansi dan tidak dipraktikan terutama di kota metropolitan seperti Jakarta. Dengan menganalisis unsur permainan tradisional yang populer sebagai dasar untuk memperkenalkan kembali permainan tradisional kepada masyarakat, serta melihat perkembangan teknologi hiburan modern sebagai katalis pengenalan program, muncul ide untuk menggabungkan unsur tradisional dan modern tersebut dalam proyek wisata hiburan. Teknologi Augmented Reality dimanfaatkan untuk memberi pengamalan baru dalam bermain permainan tradisional. Tapak terletak di daerah Kota Tua sebagai kawasan pariwisata terencana yang kondusif, didukung atmosfer kuno yang kuat dan potensi pariwisata serta fotografinya, untuk menarik pengunjung semua usia. Proyek ini juga berinteraksi dengan sekitarnya sebagai tempat yang nyaman dengan ruang terbuka untuk mempraktikan permainan tradisional secara langsung. Program didukung dengan galeri permainan tradisional, toko, workshop, dan ruang digital edukasi. Proyek ini diharapkan dapat memperkenalkan kembali permainan tradisional dan memenuhi tujuan pariwisata kota metropolitan yang sustainable.
\end{abstract}

Kata kunci: Augmented Reality; Permainan Tradisional; Simulasi; Pariwisata; Kota Metropolitan

\begin{abstract}
Jakarta as the metropolis has around 47,000 mass media which consists of print media, radio, television and online media, which makes Indonesia as the country with the most number of mass media in the world. The mass media itself became one of the factors which aspects influenced the spread of negative body image in the form of ideal body standards. Negative body image gives a negative impact both individually and socially, such as issues of body shamming, mental disorders and even eating disorders that emerging lately. The handling of negative body image has become the goal of designing this architourism project. The architectural program translated by using the phenomology method in the form of the use of the element of water and humidity and therapy techniques combined with psychology in the form of Cognitive Behavioural Therapy (CBT) in the application of the program. The resulting programs will further lead to the living body dimension (spiri) in order to balance spiritual dimension of the body in the process of renewing the perception which generally leads more to the physical dimension (physical). Other than using the element of water that able to provide the meaning of renewal for the visitors' perception regarding body-image, but simultaneously being a catalyst for enhanced the image of surrounding area, Bukit Duri area, which is a low residential area that is dense and equipped with being easy evicted and flooded image. due to its location on the lip of the Ciliwung river.Keywords: metropolis, body-image, architourism, catalyst, spiritual.
\end{abstract}

Keywords: metropolis, body-image, architourism, spiritual, catalyst. 


\section{PENDAHULUAN}

Jakarta merupakan salah satu kota metropolitan terbesar di dunia. Dengan angka pertumbuhan dan jumlah penduduk tinggi, kota harus disertai pengembangan bidang lain seperti bidang ekonomi dan sosial, salah satu caranya dengan pariwisata. Pariwisata di kota merupakan target menjanjikan, kota memiliki kecenderungan sebagai pusat perkembangan pembangunan, yang dapat terlihat pada unsur-unsur pariwisata yang lebih tersedia di kota.

Perkembangan shopping mall di Jakarta membawa dampak baik yang utama kepada nilai ekonomi, namun tidak menjawab seluruh elemen sustainabilitas pariwisata yang di dalamnya termasuk menjaga lingkungan dan alam, serta mempromosikan budaya (World Tourism Organization, 2017).

Melihat unsur kebudayaan terkait hiburan, seiring berjalannya waktu, permainan tradisional semakin dilupakan, lebih lagi tidak diteruskan ke generasi yang muda (Kovačević, 2014). Orientasi hiburan terutama bagi anak-anak berubah untuk meluangkan waktu ke video game. Selain karena perkembangan teknologi yang pesat seperti penggunaan video game dan sosial media pada gawai, permainan tradisional saat ini sulit untuk menemukan tempatnya di masyarakat karena keterbatasan ruang, dan keterbatasan informasi.

\section{KAJIAN LITERATUR}

Pariwisata, secara etimologi identik dengan kata 'travel' yaitu perjalanan yang dilakukan dengan berkali-kali dari tempat ke tempat lain, namun pariwisata memiliki sifat di luar keseharian seseorang, sehingga memberi pengalaman baru atau berbeda bagi pelakunya. Terdapat lima komponen dalam pariwisata, yaitu atraksi, amenitas, akomodasi, akses, dan atmosfer (Specht, 2014). Pariwisata perkotaan memiliki karakteristik yang berbeda, wisatawan perkotaan dapat menggunakan fasilitas perkotaan yang juga digunakan oleh penduduk kota sebagai daya tarik wisata (Law, 1996). Sebaliknya, objek wisata yang direncanakan dapat digunakan sebagai fasilitas perkotaan.

Tradisional berasal dari kata 'tradisi' (latin: traditio), memiliki arti sebagai sikap dan cara berpikir serta bertindak yang selalu berpegang teguh pada norma dan adat kebiasaan yang ada secara turun-temurun, serta menurut tradisi (adat) (KBBI, 2019). Sifat khas tradisional adalah pemberian sesuatu informasi (ilmu, aturan, dll.) secara turun-temurun, dapat tertulis maupun tidak, yang berlanjut terus-menerus, demikian pula permainan tradisional.

Permainan tradisonal tidak dapat lepas dari sebuah negara, merupakan bagian integral dari kehidupan anak-anak kecil di sebuah wilayah negara (Kovačević, 2014) oleh karena itu permainan-permainan tersebut tidak dapat dilihat di luar konteks waktu dan tempat mereka hidup sebelumnya, sehingga dengan mempelajari hal itu kita dapat melihat sejarah sebuah negara. Dalam menjaga permainan tradisional, hubungan dengan anggota generasi yang lebih tua penting, karena mereka berperan dalam memahami dan membagi pengalaman tersebut ke anak-anak. Anak-anak pun lebih memahami tradisi dan budaya, selain karena bermanfaat dalam menambah kualitas waktu bermain anak (Kovačević, 2014).

Dalam hal ini, fokus utama permainan tradisional terletak pada 10 permainan tradisional yang paling populer (Murtafi'atun, 2018): Congklak, Lompat Tali, Layangan, Kelereng, Galasing, Bentengan, Petak Umpet, Egrang, dan Engklek. Permainan-permainan ini diangkat sebagai katalis dengan menarik masyarakat yang mayortias lebih familiar kepada permainan tersebut, dan kemudian mengenalkannya dengan permainan lain dalam bentuk program-program pendukung seperti galeri.

Dalam perkembangan videogame /'esport' fisik, terdapat teknologi yang Augmented Reality. Augmented Reality. (A.R.) adalah pendekatan teknologikal yang memungkinkan sesuatu yang nyata dan virtual dilihat di bidang atau tempat yang sama yaitu dengan penggunaan objek virtual 3D dan peningkatan persepsi pada penggunanya di dunia nyata (Altinpulluk, 2016). Fungsi Augmented Reality menjadikan sebagian dunia virtual dan nyata sebagai antarmuka yang baru yang mampu menampilkan informasi yang relevan yang 
membantu dalam bidang-bidang termasuk hiburan dan edukasi. Secara fisik, terdapat perbedaan antara A.R., V.R., dan M.R., contohnya melalui persepsi terhadap sebuah buku (Grasset, 2008)

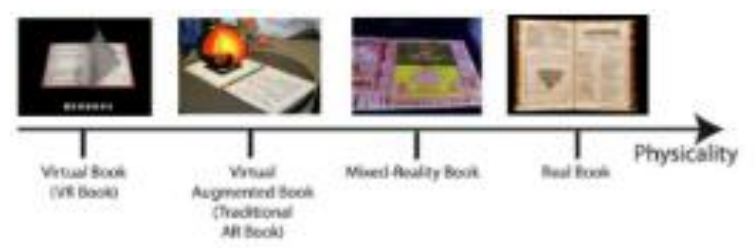

Gambar 1 - Fisikalitas Buku VR, AR, MR dan buku secara nyata Sumber: Grasset, 2008

\section{METODE}

Metode yang digunakan adalah metode kualitatif, yaitu: menggunakan studi literatur sebagai pedoman dalam menentukan standar luas sebuah ruangan seperti Neufert Architects' Data (Neufert, 2000) dan estimasi luas; melakukan pengumpulan data dengan melakukan survey di kawasan Kota Tua; menerapkan teori 5A pariwisata di kawasan Kota Tua untuk menyelesaikan permasalahan mengenai pariwisata sustainable yang mengikuti perkembangan teknologi hiburan; menggunakan elemen Augmented Reality pada program simulasi dan edukasi, dengan perangkat khusus dan gawai; menggunakan penerapan analisis kontekstual pada bangunan.

\section{DISKUSI DAN HASIL}

\section{Program}

Program didasarkan kepada visi utama proyek yaitu menjadi 'wadah' dan 'wajah' baru permainan tradisional di kota metropolitan Jakarta. Dengan mewadahi, menjadi tempat aktivitas masyarakat untuk bermain permainan tradisional dan mempelajarinya melalui galeri dan ruang simulasi permainan tradisional yang berisikan perangkat Augmented Reality, berupa kacamata A.R. dan dapat disertai benda atau alat bantu permainan tradisional. Sebagai 'wajah', bangunan menjadi wajah permainan tradisional, sebagai ikon 'eSport' fisik.

Pengadaan acara terkait di tingkat lokal dapat dinikmati berbagai kalangan dilakukan di ruang terbuka, yang dapat digunakan pula sebagai tambahan ruang bagi pengunjung Kota Tua khususnya keluarga dan anak-anak. Program yang publik ini melihat sifat pengunjung dalam pariwisata di sekitarnya yang berbeda beda, terbagi atas kategori umur yaitu: Remaja, Keluarga (anak kecil), dan Orang Tua. Dalam kategori jumlah: grup, keluarga, dan individual. Sehingga program terbagi atas program utama yaitu ruang simulasi, galeri, workshop, dan ruang digital edukasi, serta program penunjang yang dapat digunakan sebagai fasilitas bagi linkungannya yaitu restoran/café, coworking space, dan ruang terbuka yang terdapat lapangan dan area makanan tradisional.

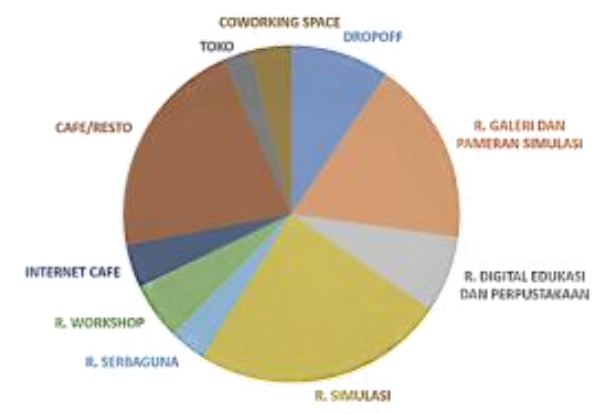

Gambar 2 - Luasan Program Utama dan Fasilitas Sumber: Dokumen Pribadi 


\section{Tapak}

Letak bangunan di Jalan Lada Dalam Raya, di kawasan Kota Tua, terpilih berdasarkan kriteria tapak yaitu: merupakan kawasan aktif yang memiliki atmosfer 'masa lalu' yang kuat, memenuhi kebutuhan elemen $5 \mathrm{~A}$ pariwisata, memiliki potensi wisata kawasan berkelanjutan yaitu rencana UDGL, dan merupakan lahan yang tidak aktif atau tidak terbangun.

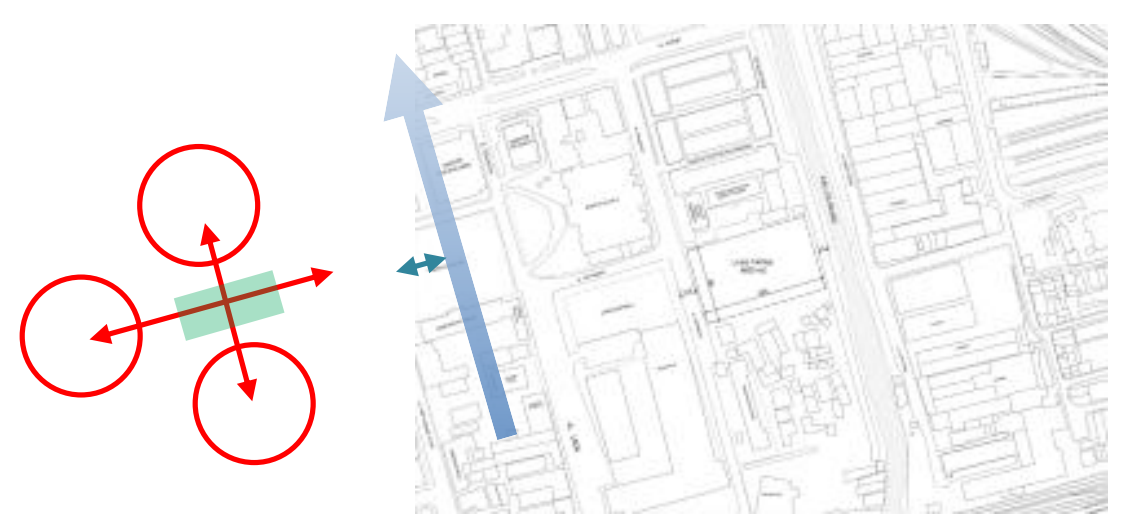

Gambar 3 - Aksis Tapak (merah) dan Sungai Ciliwung Sumber: Dokumen Pribadi

Tapak berbatasan dengan Sungai Ciliwung (Timur), sehingga perlu adanya pengembangan mendukung atraksi tepi sungai. Pada bagian selatan, berbatasan dengan perumahan dan wisma BNI, sebagai penyeimbang zona campuran di petak tapak. Pada bagian utara berbatasan dengan Kantor Kecamatan Taman Sari. Sedangkan pada bagian Timur, berhadapan langsung dengan museum sejarah Jakarta. Terdapat aksis yang kuat dan saling bersinggungan, yaitu aksis Museum Sejarah Jakarta - Tapak dan aksis Museum Seni Rupa dan Keramik - Bank BNI 46. Sementara di tengah pertemuan aksis tersebut terdapat lapangan bola yang dipagari sehingga memungkinkan visualitas dan akses yang menghubungkan bangunan itu.

\section{Konsep}

Terletak di kawasan dengan identitas khas Kota Tua, bentuk dan wujud bangunan kontekstual terhadap tapak dan sekitarnya. Berawal dari bentuk tapak persegi panjang (lihat Gambar 4, poin 1), menghadap jalan Lada Dalam, dan membelakangi jalan dan sungai Ciliwung. Pertimbangan massa, dilanjutkan dengan pembuatan jalur tembus dan orientasi ke belakang yaitu sungai karena sisi jalan utama menyesuaikan dengan aturan tampak pada UDGL Kota Tua 2018 (lihat Gambar 4, poin 2). Lantai dua dibuat terbuka, terdapat ruang luar yaitu lapangan berserta amfiteater, dan area makanan tradisional.

Selanjutnya pembentukan bidang tangkap dengan memotong massa bagian depan untuk akses masuk pengunjung dan orientasi terhadap pertigaan jalan utama, dengan mengarah ke lapangan Fatahillah (lihat Gambar 4, poin 3). Selanjutnya permainan massa pada bagian belakang dibentuk untuk fungsi Internet Kafe, Coworking Space, dan ruang-ruang terbuka berupa lapangan dan amfiteater yang dapat dimanfaatkan untuk bermain, olahraga, dan aktivitas pendukung seperti area makanan tradisional (lihat Gambar 4, point 4). Terdapat super impose bentuk fluid pada denah atau dalam bangunan yang tidak terlihat dari luar, implementasi konsep A.R. pada bangunan (lihat Gambar 4, poin 5). 


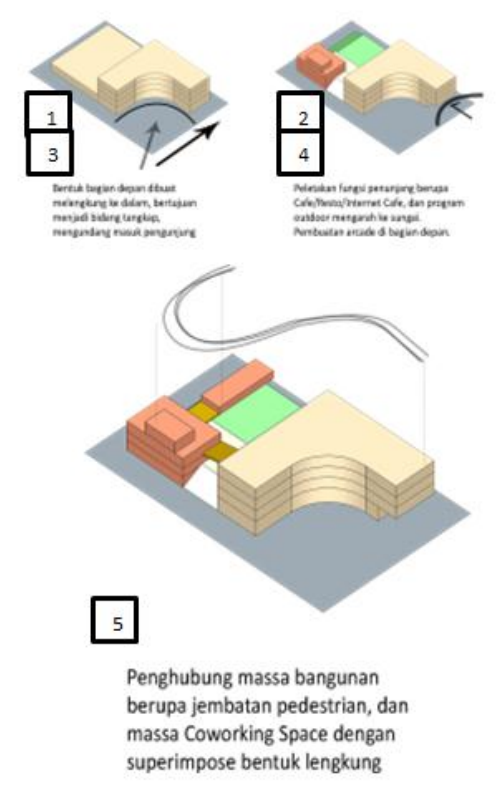

Gambar 4 - Gubahan Massa Akhir, dengan implementasi bentuk fluid sebagai penghubung. Sumber: Dokumen Pribadi

\section{Hasil Rancangan}

Berikut hasil rancangan berupa gambar denah, potongan, dan tampak beserta beberapa ilustrasi bangunan. Lantai satu merupakan daerah penerimaan dari jalan utama, area servis, retail, dan internet café serta amfiteater pada bagian belakang yang berhubungan dengan jalur pariwisata tepi sungai.

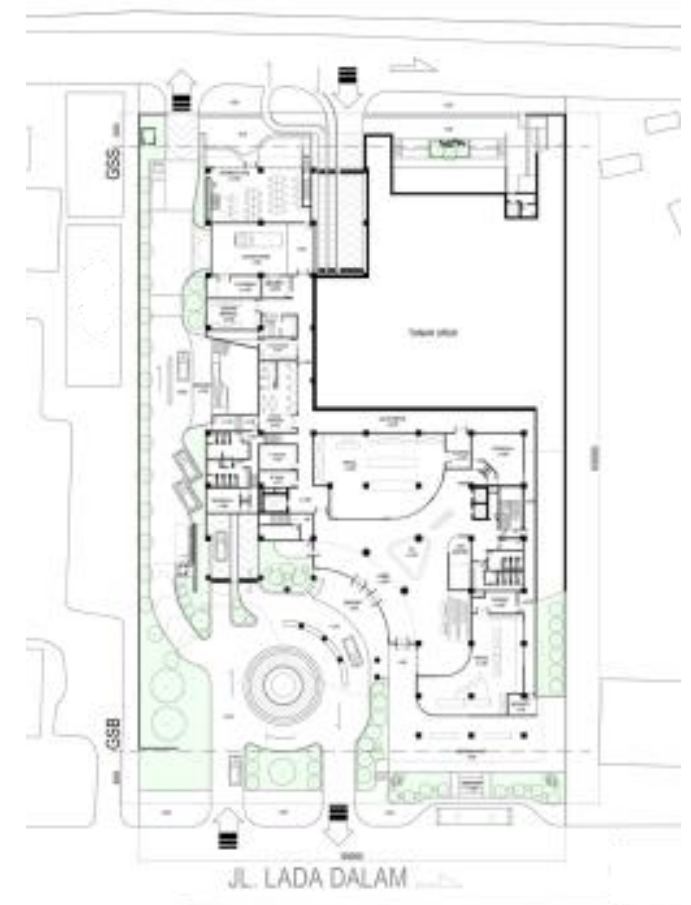

DENAH LANTAI 1

Gambar 5 - Denah Lantai 1 


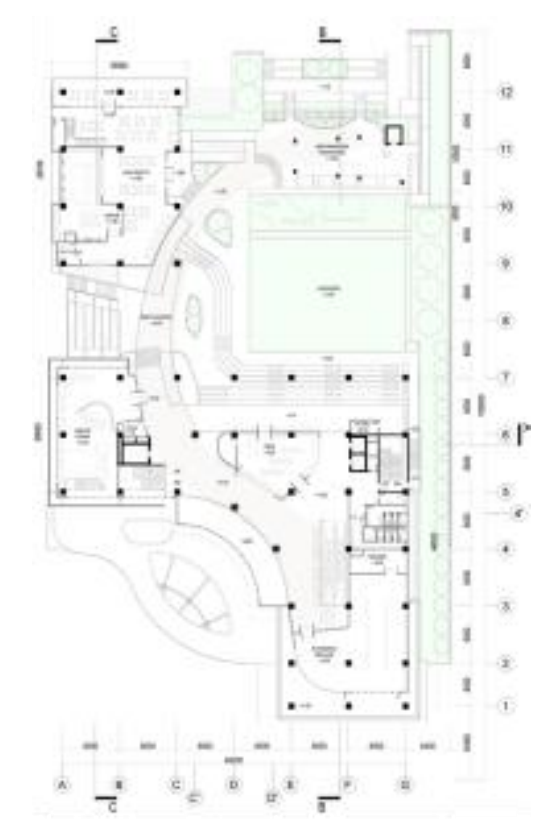

DENAH LANTAI 2 - - -

Gambar 6 - Denah Lantai 2

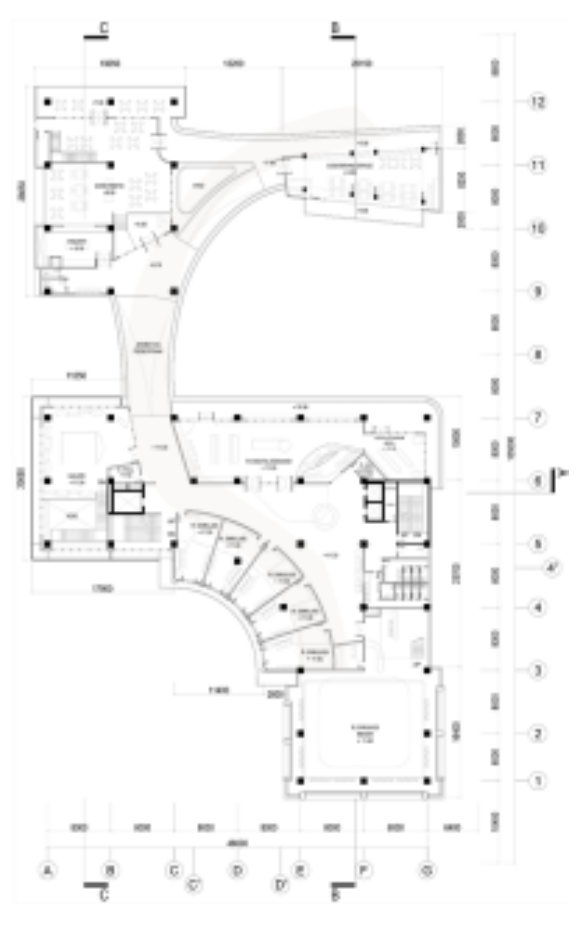

DENAH LANTAI 3 -

Gambar 7 - Denah Lantai 3 


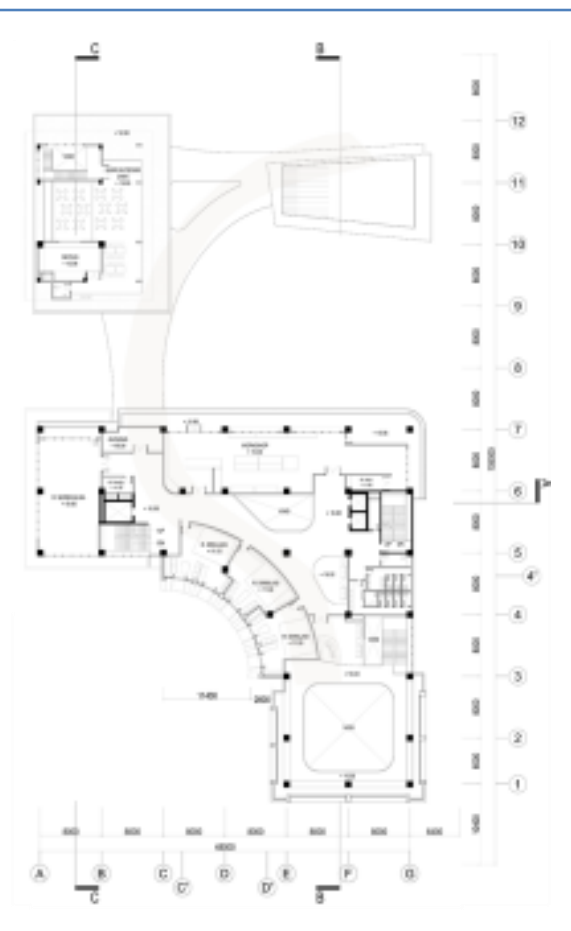

\section{DENAH LANTAI 4 - - - \\ Gambar 9 - Denah Lantai 4}

Lantai dua bersifat publik, memiliki ruang terbuka berisi lapangan, amfiteater, terdapat galeri, galeri pengenalan A.R., toko. Lantai tiga dan empat bersifat lebih privat, terdapat area simulasi, workshop, ruang digital edukasi. Bentuk fluid pada denah menghubungkan ruang sebagai sirkulasi utama, berpusat di lapangan. Dalam bangunan utama terdapat void untuk pencahayaan. Fasad bagian galeri merupakan kombinasi abjad, angka, dan pola lingkaran pada papan congklak sebagai ciri khas, dan unsur edukasi visual.

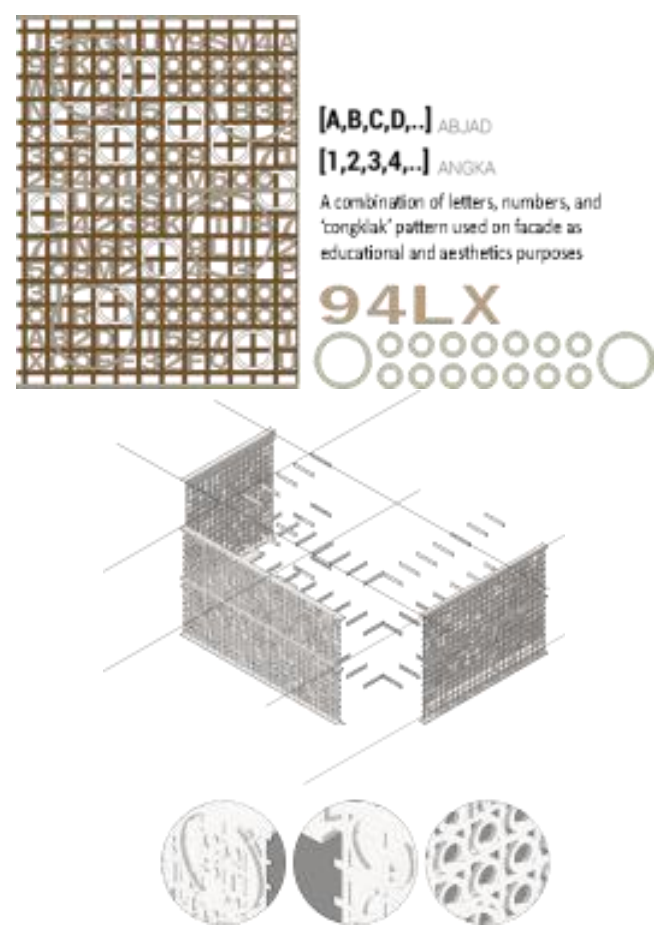

Gambar 8 - Detail Fasade (sumber: Dokumen Pribadi) 


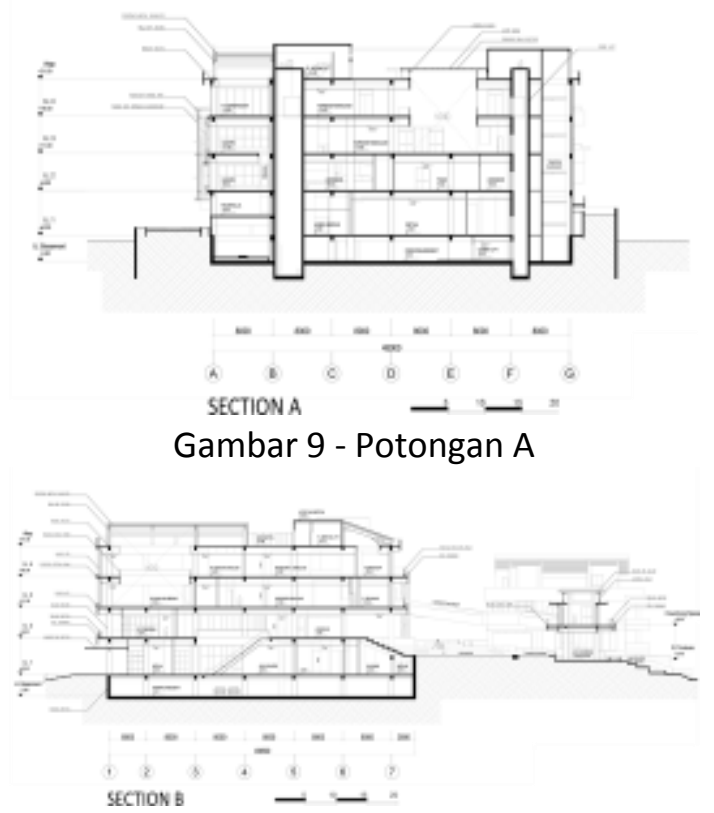

Gambar 10 - Potongan B, memperlihatkan potongan bangunan utama dan ruang publik terbuka lapangan dan amfiteater.

\section{KESIMPULAN DAN SARAN}

Pariwisata dalam kota metropolitan Jakarta membutuhkan objek wisata yang mengangkat unsur budaya lokal, yang kemudian dipersempit yaitu permainan tradisional Indonesia sebagai tema, sehingga dapat termasuk ke dalam pariwisata sustainable menurut UU. No. 10 Tahun 2009 (World Tourism Organization, 2017). Kehidupan permainan tradisional yang tertinggal dan tidak memiliki landasan kuat di ibukota, serta kebutuhan perkembangan teknologi dalam pariwisata hiburan melahirkan objek wisata baru yang menghubungkan keduanya melalui bangunan dan program proyek.

\section{UCAPAN TERIMA KASIH}

Terima kasih kepada dosen pembimbing, dosen kelas, keluarga dan teman-teman yang membantu pengumpulan data dan diskusi dalam menyelesaikan konsep desain dan program. Mohon maaf atas kesalahan dan kekurangan pada jurnal ini, semoga jurnal dapat berguna bagi pembaca.

\section{REFERENSI}

Altinpulluk, H. (2016). The Classification of Augmented Reality Books: A Literature Review. Grasset, R. (2008). The Design of A Mixed-Reality Book: Is It Still A Real Book? 2008 7th

IEEE/ACM International Symposium on Mixed and Augmented Reality.

KBBI. (2019, Januari). Diambil kembali dari KBBI: https://kbbi.web.id/

Kovačević, T. (2014). Contribution of Traditional Games to the Quality of Students' Relations and Frequency of Students' Socialization in Primary Education. Croatian Journal of Education, 95-112.

Law, C. M. (1996). Tourism in Major Cities. London: International Thomson Business Press. Neufert, E. (2000). Architect's Data - Third Edition. New Jersey: Willey-Blackwell.

Specht, J. (2014). Architectural Tourism - Building for Urban Travel Destinations. Wiesbaden: Gabler Verlag.

World Tourism Organization. (2017, September 6). UNWTO Annual Report. Diambil kembali dari UNWTO Web Site: https://www.e-unwto.org/doi/book/10.18111/9789284419807 